JAMP: Jurnal Adminitrasi dan Manajemen Pendidikan

Volume 2 Nomor 1 Maret 2019, Hal : 32-39

Tersedia Online di http://journal2.um.ac.id/index.php/jamp/

ISSN 2615-8574 (online)

\title{
KEPEMIMPINAN VISIONER KEPALA SEKOLAH DALAM MENGEMBANGKAN KARAKTER PESERTA DIDIK
}

\author{
Ika Alifiyah \\ Ali Imron \\ Juharyanto
}

\author{
Email: ika.alifiyah79@gmail.com \\ Universitas Negeri Malang, Jl. Semarang 5 No. 5 Malang 65145
}

\begin{abstract}
The focus of this research is the formulation of school vision, the shared vision process conducted by the principal, the process of implementing the vision by the principal, the principal's approach in implementing visionary leadership to develop the student's character, and the student character developed in the visionary leadership of principal. This study uses a qualitative method. Qualitative research is a study that intends to understand the phenomenon of behavior, action, the overall situation in a research subject. While the type of research used is case study research. The reason for using case studies is that this research method focuses on an intensive, detailed, and unique case.

The unique case in this study is a principal who leads for three periods of leadership, who in the process of leadership has achieved many achievements and shaped the character of learners through the values embedded in the activities at school. The results of this study are: (a) the formulation of the vision carried out by the principal involving all teachers and staff and carried out with SWOT analysis of the school; (b) the shared vision process by the principal is done through the stage of socialization, memorization, implementation, reminding and modeling, assessing and evaluating, rewarding and punishment; (c) the implementation of the vision is done through polite behavior, smile greetings, greetings, responsibilities, discipline and orderly, prioritizing KBM and maximize facilities infrastructure, and establish good cooperation with external; (d) approach in the implementation of the principal's leadership is done through MSG activities, workshop for teachers and school staff, application of $5 \mathrm{~S}$ industry culture; core value of the school, and provide an example to the school's citizens; (e) the character of the learner developed in the headmaster's leadership in islami, discipline, and responsibility that is implemented in congregational prayer activities, Dhuha Prayer, PDS, and PIC.
\end{abstract}

Keywords: leadership, vision, character of the students.

Abstrak: Fokus penelitian ini adalah perumusan visi sekolah, proses shared vision yang dilakukan oleh kepala sekolah, proses penerapan visi oleh kepala sekolah, pendekatan yang dilakukan kepala sekolah dalam implementasi kepemimpinana visioner guna mengembangkan karakter peserta didik, dan karakter peserta didik yang dikembangkan dalam implemetasi kepemimpinan visioner kepala sekolah. Penelitian ini menggunakan metode kualitatif. Penelitian kualitatif adalah penelitian yang bermaksud untuk memahami fenomena tentang perilaku, tindakan, keadaan menyeluruh pada sebuah subjek penelitian. Sedangkan jenis penelitian yang digunakan adalah penelitian studi kasus. Alasan menggunakan studi kasus adalah metode penelitian ini memusatkan perhatian pada suatu kasus yang unik secara intensif dan rinci.

Kasus unik dalam penelitian ini adalah seorang kepala sekolah yang memimpin selama tiga periode kepemimpinan, yang dalam proses kepemimpinannya telah mencapai banyak 


\begin{abstract}
prestasi serta membentuk karakter peserta didik melalui nilai-nilai yang ditanamkan dalam kegiatan-kegiatan di sekolah. Hasil penelitian iniadalah: (a) perumusan visi yang dilakukan oleh kepala sekolah melibatkan seluruh guru dan staf dan dilaksanakan dengan analisis SWOT terhadap sekolah; (b) proses shared vision oleh kepala sekolah dilakukan melalui tahap sosialisasi, dihafal, diimplementasikan, mengingatkan dan memberi teladan, dinilai dan dievaluasi, memberikan penghargaan dan hukuman; (3) penerapan visi dilakukan melalui perilaku santun, senyum salam, sapa, tanggungjawab, disiplin dan tertib, mengutamakan KBM dan memaksimalkan sarana prasarana, serta menjalin kerjasama yang baik dengan eksternal; (4) pendekatan dalam implementasi kepimimpinan kepala sekolah dilakukan melalui kegiatan MSG, lokakarya bagi guru dan staf sekolah, penerapan budaya industri $5 \mathrm{~S}$; nilai inti sekolah, serta memberikan teladan kepada warga sekolah; (5) karakter peserta didik yang dikembangkan dalam kepemimpinan kepala sekolah yakni islami, kedisiplinan, dan tanggungjawab yang diimplementasikan dalam kegiatan sholat berjamaah, Sholat Dhuha, PDS, dan PIC.
\end{abstract}

Kata Kunci:kepemimpinan, visi, karakter peserta didik

Sekolah merupakan lembaga pendidikan yang menjadi suatu sistem, dimana artinya segala halnya yang ada di sekolah memiliki peran yang penting saling mengisi dan berkaitan. Sistem tersebut yang akan mengembangkan kemampuan dan karakter dari peserta didik yang dibina di sekolah tersebut agar nantinya akan menghasilkan output dan menciptakan outcome yang cakap bagi sekolah, masyarakat, negara, serta agamanya. SDM merupakan kunci utama penggerak suatu sistem organisasi, oleh karena itu suatu sekolah harus memiliki SDM yang baik dan berkualitas. Kunci utama agar perencanaan, program-program pengembangan pendidikan, serta pengembangan karakter peserta didik di sekolah berjalan optimal berada di tangan para pendidik dan tenaga kependidikan juga komponen SDM lainnya di sekolah. SDM yang baik dan berkualitas tentunya tercetak dari lingkungan dan manajemen yang baik, serta kepemimpinan yang baik.

Seorang kepala sekolah sebagai bagian dari tenaga kependidikan sekaligus seorang pemimpin dalam sebuah lembaga pendidikan memiliki peran penting dalam pengembangan karakter peserta didik melalui ketrampilan kepemimpinannya. Dalam memimpin sebuah lembaga kepala sekolah menjadi salah satu pelaku utama penentu visi dan tujuan sekolah sebagai arah gerak lembaga yang dipimpinnya. Visi dan tujuan sekolah tersebut menjadi landasan pembelajaran baik dalam lingkup akademis maupun non akademis. Hal ini akan merupakan salah satu upaya kepemimpinan kepala sekolah dalam mengembangkan karakter peserta didiknya. Di sekolah ini karakter yang begitu terasa adalah nilai kedisiplinan yang diterapkan.

Kepemimpinan seorang kepala sekolah adalah kemampuannya dalam mengelola/memanajemen segala sumber daya yang ada serta mempengaruhi, membimbing, mengarahkan seluruh warga sekolahnya untuk bisa ikut berpartisipasi aktif, berkontribusi, serta mendukung segala program dan aktivitas sekolah yang merupakan misi dan visi dari sekolah. Karena visi sekolah adalah kemudi dari sebuah sistem sekolah dan pemimpin atau kepala sekolah adalah pemegang kendalinya. Implementasi penerapan kepemimpinan visioner di SMK Muhammadiyah 7 Gondanglegi ini merupakan salah satu keunikan karena sekolah ini memiliki letak lokasi yang cukup jauh dari ibu kota namun bisa mendapatkan beragam prestasi dan penghargaan dari pemerintah, serta sebagai salah satu sekolah rujukan nasional dan SMK model.Selain itu kepemimpinan kepala sekolah juga diwujudkan dalam berbagai macam prestasi baik yang diraih oleh kepala sekolah, guru, staf, hingga peserta didik. Selain prestasi diatas peneliti mendapatkan informasi bahwasanya sekolah juga memiliki gedung SMK terbesar di Indonesia yang disebut dengan "The Titanium Building", yang pada saat ini dalam proses melanjutkan pembangunan yang direncanakan sebelumnya yaitu 7 lantai. Sekolah ini juga mendapatkan apresiasi dari pemerintah yang berupa bangunan Teaching Factory yang telah diresmikan pada 14 April 2017 oleh Mendikbud. Prestasi-prestasi yang telah diraih ini tentunya berpijak pada visi yang telah ditetapkan oleh kepala SMK Muhammadiyah 7 Gondanglegi yaitu: menjadi sekolah Islami, unggul, professional, 
entrepreneur, dan bertaraf internasional. Sehingga implementasi kepemimpinan visioner kepala sekolah ini mengembangkan nilai-nilai kepada peserta didik sehingga membentuk karakter melalui pembiasaanpembiasaan dalam kegiatan di sekolah.

\section{METODE}

Pendekatan yang digunakan dalam penelitian ini adalah pendekatan kualitatif, jenis penelitian studi kasus. Penelitian ini bermaksud untuk mengetahui secara mendalam kepemimpinan visioner kepala SMK Muhammadiyah 7 Gondanglegi dalam mengembangkan karakter peserta didik di sekolah. Alasan menggunakan studi kasus yaitu memusatkan perhatian pada suatu kasus yang unik secara intensif dan rinci. Sumber data dalam penelitian ini yaitu kepala sekolah, wakil kepala sekolah bagiankesiswaan (Waka Kesiswaan), Management Representative (MR),kepala program studi (Kaprodi), guru mata pelajaran, guru piket, pesrta didik, dan alumni. Waka Humas sebagai informan kunci terkait sistem pembelajaran 4 tahun. Pengumpulan data dilakukan dengan menggunakan teknik wawancara, observasi, dan dokumentasi. Analisis data dilakukan sejak sebelum peneliti memasuki lapangan, selama di lapangan dan setelah selesai di lapangan. Analisis data dilaksanakan bersamaan dengan pengumpulan data. Dalam analisis data, peneliti mereduksi data yang telah didapatkan lalu memilah setiap data sesuai fokus dan selanjutnya membuat kesimpulan pada masing-masing temuan fokus. Setelah proses analisis data maka dilanjutkan dengan pemeriksaan keabsahan temuan informasi menggunakan teknik triangulasi (sumber, metode/teknik, dan waktu), pengecekan anggota, perpanjangan waktu pengamatan, dan kecukupan bahan referensi.

\section{HASIL}

Visi yang telah dirumuskan pada tahun 2009 oleh sekolah ini adalah "Menjadi sekolah yang Islami, unggul, professional, entrepreneur, dan bertaraf internasional." Proses perumusan visi yang dilakukan oleh kepala sekolah miliputi: 1) mengumpulkan seluruh guru dan staf untuk merumuskan visi sekolah; 2) melakukan analisis SWOT terhadap sekolah; 3) menampung saran, masukan, dan referensi sebagai bahan pertimbangan; 4) merumuskan visi yang bisa mengakar dan akan menjadi budaya baru sekolah dengan pelibatan seluruh guru dan staf, berdasarkan kondisi sekolah dan merombak visi yang telah ada sebelumnya; 5) membentuk tim kecil sejumlah lima orang.

Proses shared vision yang dilakukan oleh kepala sekolah adalah: 1) sosialisasi kepada seluruh elemen. Mulai dari Pendidik dan Tenaga Kependidikan (PTK), peserta didik, orangtua/wali peserta didik, serta masyarakat luas. Visi ini dicantumkan di berbagai media dan tempat yang mudah dilihat dan dijangkau; 2) setiap PTK dan peserta didik di sekolah wajib menghafal visi dan core value sekolah; 3) visi sekolah ini diimplementasikan oleh setiap unit kerja, staf kepemimpinan, dan juga peserta didik. Implementasi dari visi ini adalah bentuk dari jabaran indikator-indikator yang telah dirancang dalam bentuk kegiatan. Islami yaitu melalui cerminan sikap dan perilaku. Unggul melalui produk dan pembelajarannya. Professional dalam memberikan layanan serta fasilitas yang berkualitas kepada peserta didik dan masyarakat. Entrepreneur, memiliki jaringan, prospek dan penempatan kerja. Bertaraf internasional melalui prestasi yang diraih dari lomba-lomba dan kerjasama; 4) kepala sekolah akan mengingatkan visi dari sekolah. Dalam kegiatan sehari-hari kepala sekolah juga sering kali mengingatkan bagaimana bersikap dan berperilaku sesuai dengan visi sekolah; 5) kepala sekolah melakukan penilaian dan evaluasi terhadap kinerja PTK.

Implementasi visi dalam kepemimpinan kepala sekolah yaitu: 1) Islamidibuktikan dalam perilaku senyum, salam, sapa, disiplin. Kebersihan dan sekolah yang kondusi, mengenakan seragam dengan rapi, melaksanakan kegiatan-kegiatan keagamaan seperti sholat berjamaah dan Sholat Dhuha, serta manajemen yang baik; 2) unggul melalui proses pembelajarannya, rapor peserta didik menggunakan sistem K13 yang telah diadaptasi oleh sekolah, pelayanan yang diberikan baik kepada peserta didik maupun kepada orang diluar sekolah, kepala sekolah selalu meminta persiapan yang maksimal sebelum hari $\mathrm{H}$ dilaksanakannya kegiatan, sarana dan prasarananya yang memadai karena bekerjasama dengan 
dunia industri sebagai bentuk miniatur dari dunia kerja; 3) professionalmelalui PTK bekerja secara maksimal, tugas pendisiplinan melalui guru piket untuk melakukan pendataan terhadap seluruh peserta didik yang sebelumnya absen dan tidak hadir dalam kegiatan KBM baik berupa ijin orangtua, sakit, ataupun alpha; 4)entrepreneur dibuktikan dengan setiap peserta didik sudah mulai diperkenalkan dengan budaya industry, guru dan peserta didik dituntut untuk bisa menghasilkan sebuah produk unggulan melalui adanya teaching factory yang telah disediakan oleh sekolah; 5)bertaraf internasional dibuktikan dengan prestasi yang dicapai, prestasi ini meliputi studi lanjut ke luar negeri, kerjasama sekolah, mengikuti lomba-lomba di luar negeri, serta workshop ataupun studi banding bagi PTK, kepala sekolah juga mendapatkan berbagai macam penghargaan dan prestasi; 6) kebijakan-kebijakan yang diterapkan oleh kepala sekolah; 7) pembangungan infrastruktur sekolahThe Titanium Building(TTB), graha teknologi, teaching factory, serta perluasan lahan dan pembangunan gedung-gedung lain.

Pendekatan yang dilakukan oleh kepala sekolah dalam implementasi kepemimpinannya guna mengembangkan karakter peserta didik adalah: 1)penerapan $5 \mathrm{~S}$ yang meliputi Seiri (Ringkas), Seiton (Rapi), Seiketsu (Resik), Seiso (Rawat), dan Setsuke (Rajin); 2) pelaksanaan Morning Spiritual Gathering(MSG) bagi PTK; 3) memberikan workshop kepada PTK untuk mengembangkan kompetensi, keterampilan, dan wawasan; 4) memberikan kepercayaankepada peserta didik sebagai PIC, peserta didik berkontribusi dalam penilaian kinerja guru dan kondisi sekolah; 5) Modeling yang diberikan oleh kepala sekolah.

Karakter yang dikembangkan dalam implementasi kepemimpinan visioner kepala sekolah yaitu: 1) disiplin, nilai ini dikembangkan oleh melalui kehadiran dalam setiap kegiatan, bersikap dan berperilaku, pelaksanaan budaya industri 5A, green line, serta KBM; 2) tanggungjawab, nilai ini dikembangkan melalui PIC yang dibebankan kepada peserta didik, punishment yang harus dilaksanakan ketika peserta didik absen/tanpa keterangan saat tidak masuk sekolah, kebersihan sekolah; 3) Islami/keagamaan, nilai ini dikembangkan dalam kegiatan Sholat Dhuhur, Ashar, dan Maghrib serta Sholat Dhuha berjamaah., serta kegiatan membaca Al Quran sebelum Sholat Dhuha dilaksanakan, juga sebelum KBM dimulai; 4) tertib, nilai ini dikembangkan melalui prosedur izin yang harus dilaksanakan peserta didik ketika tidak masuk sekolah yaitu melalui izin orangtua/wali disertai dengan bukti fisik, yang kemudian akan dikonfirmasi oleh peserta didik. Selain itu juga ada surat pengantar offeringyang disertai izin guru piket bagi peserta didik yang pulang sebelum waktunya; 5) enterpreneur, nilai ini dikembangkan melalui target dan tantangan yang diberikan oleh kepala sekolah agar peserta didik bisa menciptakan produk unggulan sesuai dengan jurusannya; 6) bertaraf internasional, nilai ini dikembangkan melalui berbagai macam kegiatan lomba yang ditawarkan oleh kepala sekolah agar diikuti serta melalui kerjasama dan pertukaran pelajar.

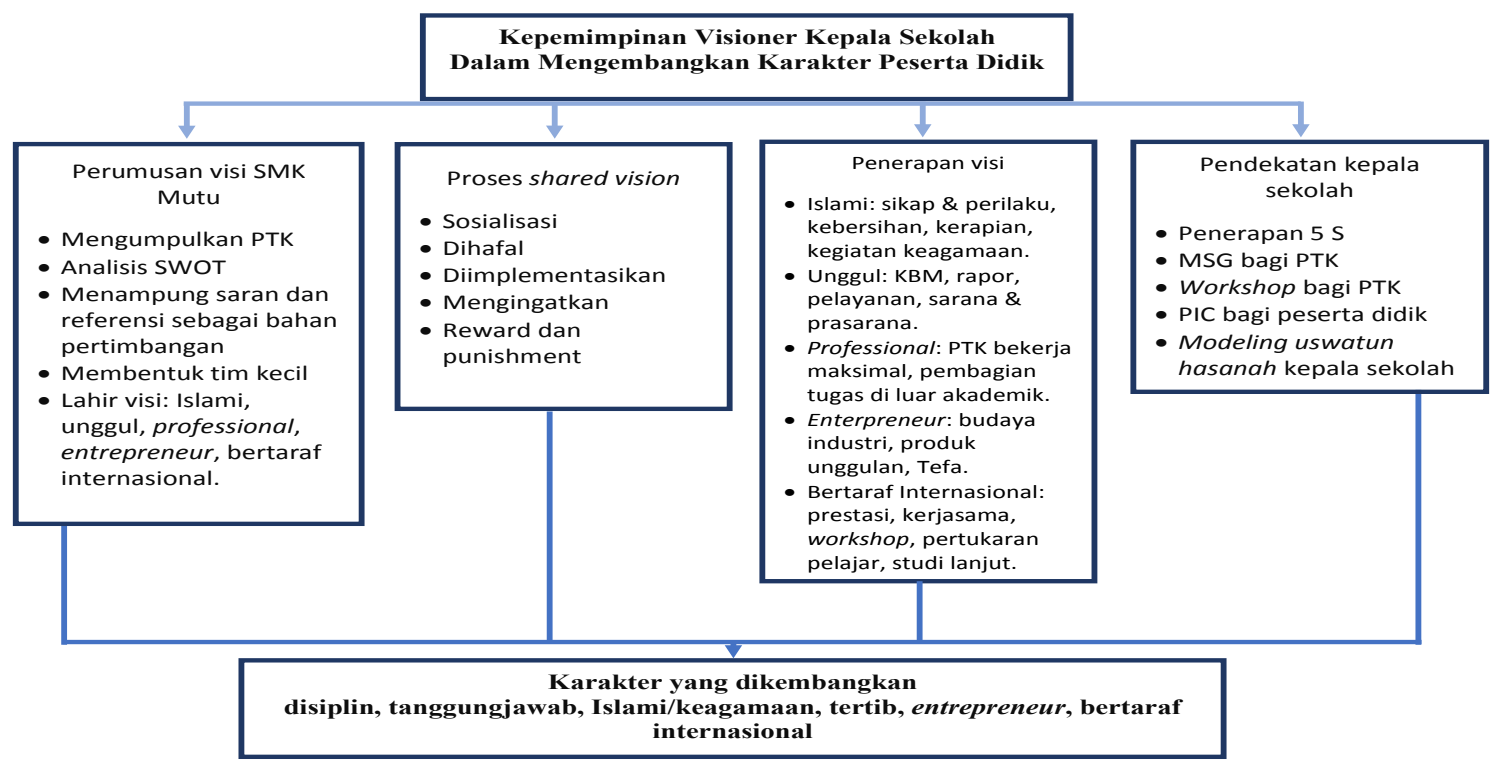

Gambar Kepemimpinan Visioner Kepala Sekolah dalam Mengembangkan Karakter Peserta Didik 


\section{PEMBAHASAN}

\section{Perumusan Visi yang Dilakukan Oleh Kepala Sekolah}

Sebagai seorang pemimpin, kepala SMK Muhammadiyah 7 Gondanglegi memiliki sebuah pandangan dan impian akan dibawa ke mana sekolah yang dipimpinnya. Pandangan ini akan berpengaruh terhadap perubahan lembaga beserta elemen dan komponen sekolah. Agar dapat membawa pengaruh yang posotif, pandangan ini disusun melalui sebuah perumusan visi sekolah. Hal tersebut sesuai dengan pendapat Komariah \& Triatna (2010: 81) bahwa visi dapat mengisi kehampaan, membangkitkan semangat, menumbuhkan kinerja, serta mewujudkan prestasi pendidikan, apalagi di tengah-tengah tuntutan kemandirian berpikir dan bertindak. Visi ini merupakan sebuah ide atau gagasan yang dituangkan dalam bentuk aspirasi berdasarkan analisis kondisi sekolah untuk bisa mencapai sebuah tujuan bersama.

Hasil temuan terkait perumusan visi yang dilakukan oleh kepala sekolah yaitu melalui beberapa tahapan. Dimulai dari kepala sekolah mengumpulkan seluruh guru dan staf sekolah dalam rangka merumuskan visi bersama. Hal ini dilakukan karena perubahan sekolah harus dilakukan bersama dengan berpijak pada visi yang dirumuskan bersama. Visi ini nantinya akan dijadikan sebuah pedoman dalam setiap tindakan oleh setiap warga sekolah. visi yang akan disusun ini harus mengakar dan membentuk suatu budaya sekolah sesuai dengan harapan di masa yang akan datang.

Pelibatan seluruh guru dan staf atau yang bisa disebut dengan PTK ini harapannya agar bisa mempermudah proses analisis kondisi sekolah untuk dikoordinasikan dengan tim kecil yang telah dibentuk. Pembentukan tim kecil ini yang melahirkan goal berupa visi sekolah dengan segala pertimbangan yang dilakukan.

\section{Proses Shared Vision yang Dilakukan Oleh Kepala Sekolah}

Kepala sekolah melakukan sebuah proses shared vision untuk mencapai tujuan yang akan dicapai di masa yang akan datang.Dalam proses ini kepala sekolah mensosialisasikan, mengkomunikasikan, dan mengarahkan seluruh komponen sekolah untuk bersama mendukung dan berkontribusi dalam pencapaian visi. Melalui proses ini sekolah akan mendapatkan komitmen dari warga sekolah dalam penerapan nilainya, komitmen ini merupakan sebuah awal mental investment yang akan terbentuk dengan usaha mencapai sebuah visi sekolah melalui proses shared vision yang dilakukan kepala sekolah dengan seluruh komponen sekolah. Kepala sekolah memberikan pesan-pesan kepada seluruh komponen sekolah melalui strategi yang diterapkan untuk membentuk SDM yang berkarakter. Seperti halnya yang dikemukakan oleh Peterson \& Deal (dalam Diyati \& Muhyadi, 2014: 30), kepala sekolah memiliki peran yang paling pokok yaitu mengkomunikasikan nilai-nilai, perilaku, dan harapan-harapan kepada seluruh warga sekolah yang diwujudkan dalam bentuk tindakan seperti ucapan, pesan, maupun perilaku non verbal.

Beberapa strategi yang dilakukan oleh kepala sekolah yaitu sosialisasi, dihafal, diimplementasikan, mengingatkan, dinilai dan dievaluasi, serta memberikan reward dan punishment. Visi sekolah dimiliki oleh semuanya dan dilaksanakan pula oleh semuanya. Hal tersebut dibuktikan melalui yang pertama prestasi yang telah diraih kepala sekolah dan seluruh komponen sekolah. Prestasi yang telah diraih kepala sekolah ini adalah salah satu bentuk shared vision kepada komponen sekolah, sehingga mereka tergerak untuk turut serta memberikan prestasi bagi sekolah.

Dalam hal ini kepala sekolah memberikan peluang yang lebar bagi peserta didik, guru dan staf agar berprestasi dan juga akan diberikan kesempatan untuk studi ke luar negeri guna mendapatkan wawasan dan pengalaman yang akan berdampak positif untuk mewujudkan visi sekolah.

Komunikasi dan interaksi dilakukan sebagai salah satu upaya meningkatkan komunikasi dalam proses shared vision yakni melalui rapat, diskusi maupun tatap muka. Kepala sekolah memberikan teladan-teladan dalam setiap tindakan dan tingkah lakunya. Teladan yang diberikan ini merupakan penerjemahan visi ke dalam bentuk seperti yang telah dijelaskan diatas. Teladan yang dilakukan oleh kepala sekolah sebagai pemimpin, teladan oleh guru dan staf kepada peserta didiknya. Hal ini dilakukan dengan tujuan agar visi tersebut bisa dipahami oleh seluruh warga sekolah. Pernyataan tersebut sesuai dengan pendapat yang disampaikan Gunawan \& Benty (2017: 545) bahwa pemimpin adalah seseorang 
yang seharusnya melihat jauh ke depan, seseorang yang menciptakan pembaharuan dengan pemikiranpemikirannya yang diikuti oleh anak buahnya. Teladan yang dilakukan ini secara tidak langsung adalah bentuk dari implementasi visi itu sendiri. Jadi semua orang tergerak untuk melakukannya karena rasa memiliki.

Berdasarkan hasil temuan penelitian dengan landasan teori di atas menyimpulkan bahwasanya proses shared vision tersebut diartikan dalam dua makna, yakni visi bersama dan penjabaran visi. Dua makna inipun saling berkaitan, karena dalam penerapannya keduanya merupakan serangkaian proses. Proses shared vision yang diterapkan oleh Kepala SMK Muhammadiyah 7 Gondanglegi yaitu meliputi: a) sosialisasi; b) dihafal oleh seluruh warga sekolah; c) implementasi; d) mengingatkan; e) penilaian.

\section{Proses Penerapan Visi yang Dilakukan Oleh Kepala Sekolah}

Perilaku senyum, salam, sapa, disiplin, tertib, dan santun adalah penerapan nilai dari visi Islami oleh SMK Muhammadiyah 7 Gondanglegi. Perilaku tersebut dilakukan oleh setiap orang di sekolah mulai dari guru, staf, hingga peserta didik.

Proses pembelajaran yang didukung dengan sarana dan prasarana yang memadai serta proses pengajaran yang maksimal, pemberian pelayanan yang baik kepada setiap orang adalah penerapan nilai-nilai dari visi unggul di sekolah. dari KBM dan pelayanan yang maksimal tersebut menghasilkan produk-produk yang unggul yang bisa bersaing dengan sekolah lain di kancah nasional serta mulai dikenalkan juga di lingkup internasional.

Setiap pekerjaan dilakukan dengan penuh tanggungjawab sehingga nilai professional ini dapat diimplementasikan dengan baik oleh setiap PTK, setiap orang turut bertanggungjawab pula dalam kebersihan dan ketertiban sekolah agar KBM dan kegiatan lainnya dapat berjalan dengan kondusif. Hal ini sejalan dengan yang disampaikan oleh Mulyasa (2012: 14) bahwa ada 8 hal yang perlu diperhatikan dalam menyukseskan pendidikan karakter di sekolah, yaitu: 1) memahami hakikat pendidikan karakter; 2) mensosialisasikan dengan dengan tepat; 3) menciptakan lingkungan yang kondusif; 4) mengembangkan sarana dan sumber belajar yang memadai; 5) mendisiplinkan peserta didik; 6) memilih kepala sekolah yang amanah; 7) mewujudkan guru yang dapat digugu dan ditiru; 8) melibatkan seluruh warga sekolah dalam menyukseskan pendidikan karakter.

Penerapan dari visi tersebut tak lepas dari ketrampilan kepemimpinan kepala sekolah, sehingga mulai dari awal kepemimpinan hingga saat ini SMK Muhammadiyah 7 Gondanglegi memiliki brand SMK Mutu yakni sebagai SMK rujukan yang berprestasi. Hal ini merupakan energi positif dari perkembangan implementasi nilai-nilai visi yang dipegang bersama oleh seluruh warga sekolah, sehingga dampaknya bagi perubahan sekolah sangat baik. Hal tersebut sesuai dengan pendapat yang disampaikan oleh Imron (2015: 1) bahwa kepala sekolah sebagai bagian dari tenaga kependidikan mempunyai posisi strategis. Yakni sebagai manajer yang bertanggungjawab dalam mendayagunakan semua sumber daya sekolah untuk mencapai tujuan, dan sebagai supervisor yang bertanggungjawab dalam meningkatkan dan menentukan kualitas pembelajaran guru.

\section{Pendekatan yang Dilakukan Oleh Kepala Sekolah dalam Implementasi Kepemimpinan Visioner Guna Mengembangkan Karakter Peserta Didik}

Secara garis besar dalam pengamatan lapangan peneliti menemukan beberapa pendekatan yang dilakukan oleh kepala sekolah yakni melalui budaya MSG yang diperuntukkan kepada seluruh PTK yang dilaksanakan setiap hari pada pukul 6.30 WIB sampai dengan lebih kurang 7.00 WIB yang dipimpin langsung oleh kepala sekolah. Dalam kegiatan MSG ini berisikan pembacaan hadist-hadist oleh kepala sekolah, penyampaian informasi, pemberian motivasi, doa, dan ditutup dengan saling jabat tangan oleh seluruh PTK. Tujuan dari MSG sendiri adalah selain untuk mendisiplinkan guru, dan memberi motivasi juga memberikan teladan dan pelayanan yang baik terhadap peserta didik dengan datang lebih awal di sekolah. Hal tersebut sesuai dengan pendapat yang disampaikan oleh Amri, S. dkk. (2011: 110-111) bahwa sekolah membantu orangtua mengerjakan kebiasaan-kebiasaan yang baik serta menanamkan budi pekerti yang baik serta memberikan pelajaran etika, keagamaan, estetika, membenarkan benar atau salah dan sebagainya.Kemudian, salah satu upaya untuk meningkatkan kompetensi PTK yaitu melalui kegiatan workshop. 
Kebijakan-kebijakan khusus terkait peserta didik yang diterapkan oleh kepala sekolah adalah peserta didik harus datang tepat waktu, peserta didik perempuan tidak diperkenankan memakai make up, peserta didik tidak diperkenankan membawa handphone ke sekolah. Disamping itu kepala sekolah juga ingin memberikan pelayanan yang maksimal kepada peserta didik. Begitu halnya yang disampaikan Susanto \& Muhyadi (2016: 152) bahwasanya peranan penting kepala sekolah dalam peningkatan kualitas Pendidikan adalah sebagai motor penggerak dan penentu arah kebijakan sekolah.

Selain itu, seorang kepala sekolah juga sebagai modelling dengan memberikan teladan serta sikap dan perilaku lain yang baik sebagai bentuk kepemimpinannya.Dalam pembiasaan di kegiatan seharihari ditemukan pembacaan core valuesekolah, piket dan controlling yang dijalankan oleh setiap unit sebagai bentuk penanaman nilai disiplin dan tanggungjawab. Hal ini disampaikan oleh Mulyasa (2012: 3) bahwasanya pendidikan karakter tidak hanya berkaitan dengan masalah benar-salah, tetapi bagaimana menanamkan kebiasaan (habit) tentang hal-hal yang baik dalam kehidupan, sehingga anak/peserta didik memiliki kesadaran, pemahaman yang tinggi, serta kepedulian dan komitmen untuk menerapkan kebajikan dalam kehidupan sehari-hari.

\section{Karakter Peserta Didik yang Dikembangkan dalam Implementasi Kepemimpinan Visioner Kepala Sekolah}

Karakter peserta didik yang dikembangkan oleh kepala SMK Mutu ini berawal dari keinginan yang dituangkan dalam visi sekolah. Berangkat dari visi itulah kepala sekolah bersama guru dan staf menerjemahkannya ke dalam kegiatan-kegiatan yang dapat mengembangkan karakter-karakter atau nilai dari visi tersebut. Dengan diterjemahkan ke dalam kegiatan sekolah yang lebih sederhana ini peserta didik akan mengamalkan nilai-nilai yang dikembangkan oleh sekolah serta secara tidak langsung menjadi pendidikan nilai. Adapun nilai-nilai utama berusaha kepala sekolah kembangkan antara lain adalah islami, kedisiplinan, dan tanggungjawab. Dari tiga nilai tersebut dijumpai di lapangan tampak dalam kegiatan seperti: kebersihan, pembacaan Al Quran sebelum sholat dhuha berjamaah dan sebelum PBM, sholat wajib berjamaah, Penegak Disiplin Sekolah (PDS), pembagian Person In Charge (PIC), dan lain sebagainya. Hal tersebut sesuai dengan pendapat yang disampaikan oleh Amri, S., dkk. (2011: 42) bahwa karakter Pendidikan harus dimasukkan ke dalam iklim dan rutinitas sehari-hari sekolah. Nilainilai kedisiplinan di SMK Muhammadiyah 7 Gondanglegi ini ditampakkan melalui kehadiran yang tepat waktu, mematuhi kebijakan-kebijakan yang telah ditetapkan, bersedia menerima konsekuensi jika melanggar kedisiplinan. Hal ini tampak pada punishment yang diberikan setiap harinya kepada peserta didik yang melanggar. Hal ini sejalan dengan ungkapan Aristoteles dalam Mulyasa (2012: 3) karakter erat kaitannya dengan habit atau kebiasaan yang terus-menerus dipraktikkan atau diamalkan.Nilai islami/agamis di sekolah ini ditunjukkan melalui kegiatan Sholat Dhuha, Dhuhur, Ashar, dan Maghrib berjamaah, selain itu juga peserta didik membaca Al Quran sebelum melaksanakan sholat atau sebelum memulai KBM. Disamping itu nilai tanggungjawab yang ingin dikembangkan oleh kepala sekolah ini tampak dari kegiatan pendisiplinan. Peserta didik yang mengikuti Ikatan Pelajar Muhammadiyah (IPM) diberikan amanah tambahan berupa PDS. PDS bertugas membantu guru piket setiap harinya untuk menertibkan peserta didik yang akan diberikan tindak lanjut dari absen kehadiran di hari sebelumnya. Setiap peserta didik juga sangat tertib ketika melaksanakan setiap kegiatan, salah satunya menata setiap sepatunya masing-masing dengan rapi ketika sholat berjamaah. Hal ini serupa dengan yang disampaikan oleh Lickona dalam Mulyasa (2012: 4) yaitu" desiring the good" atau keinginan untuk melakukan kebajikan. Hal serupa dijelaskan juga bahwasanya pendidikan karakter yang baik harus melibatkan bukan hanya aspek "knowing the good", tetapi juga "desiring the good" atau "loving the good" dan "acting the good", sehingga manusia tidak berperilaku hanya sekadarnya dan sewajarnya aturan tetapi lebih dari itu. 


\section{KESIMPULAN}

1) Perumusan visi dengan mengumpulkan seluruh guru dan staf sekolah dalam rangka merumuskan visi bersama. Setelah itu kepala sekolah bersama dengan seluruh PTK melakukan analisis SWOT terhadap kondisi sekolah pada saat itu. Selanjutnya kepala sekolah menampung saran sebagai bahan pertimbangan. Visi tersusun melalui pembentukan tim kecil; 2) Proses shared vision dilakukan melalui: sosialisasi yang dilakukan kepada seluruh komponen sekolah hingga kepada masyarakat luas, dihafal oleh seluruh komponen di sekolah, diimplementasikan ke dalam perilaku dan setiap kegiatan-kegiatan sekolah, kepala sekolah mengingatkan setiap personal dalam berperilaku melalui teguran dan teladan, implementasi tersebut dinilai dan dievaluasi, kepala sekolah memberikan reward dan punishment kepada seluruh komponen; 3) Penerapan visi dilakukan melalui: (a) senyum, salam, sapa, disiplin, tertib, dan santun; (b) proses pembelajaran yang berkualitas didukung dengan sarana dan prasarana yang memadai serta proses pengajaran yang maksimal, pemberian pelayanan yang baik kepada setiap orang; (c) setiap pekerjaan dilakukan dengan penuh tanggungjawab;(d) kerjasama yang dijalin antara sekolah dengan pihak eksternal dan prestasi yang diraih;(e) pembangunan gedung/infrastruktur sekolah; 3) Pendekatan dalam implementasi visi yang dilakukan oleh kepala sekolah yakni melalui Morning Spiritual Gathering (MSG) yang dilakukan oleh seluruh Pendidik dan Tenaga Kependidikan (PTK) dipimpin oleh kepala sekolah setiap pagi selama lebih kurang 15 menit, dimulai pukul $6.30 \mathrm{WIB}$, berbagai macam kegiatan workshop untuk meningkatkan kompetensi dan keterampilan PTK, penerapan budaya industri 5 S, core valuesekolah, dan teladan yang diberikan sebagai pembelajaran bagi peserta didik dan guru; 5) Karakter peserta didik yang dikembangkan oleh kepala sekolah antara lain adalah islami, kedisiplinan, dan tanggungjawab. Tiga nilai tersebut tampak dalam kegiatan seperti: kebersihan, pembacaan Al Quran sebelum sholat dhuha berjamaah dan sebelum PBM, sholat wajib berjamaah, Penegak Disiplin Sekolah (PDS), pembagian Person In Charge (PIC), dan lain sebagainya.

\section{SARAN}

Bagi peneliti lain yang memiliki tema penelitian yang serupa disarankan untuk mengembangkan teori lebih luas yang berkaitan dengan kepemimpinan visioner kepala sekolah dalam mengembangkan karakter peserta didik.

\section{DAFTAR RUJUKAN}

Amri, S. Jauhari, A. \& Elisah, T. 2011. Implementasi Pendidikan Karakter dalam Pembelajaran (Strategi Analisis dan Pengembangan Karakter Siswa dalam Proses Pembelajaran). Jakarta: PT. Prestasi Pustakaraya.

Diyati, H. \& Muhyadi. 2014. Peran Kepemimpinan Kepala Sekolah dalam Pengembangan Budaya Sekolah di SDN Kawayuhan, Kecamatan Minggir, Sleman. Jurnal Akuntabilitas Manajemen Pendidikan, (Online), 2 (1): 30, (http://journal.uny.ac.id/index.php/jamp/article/view/2407), diakses 25 November 2017.

Gunawan, I \&Benty, D. 2017. Manajemen Pendidikan Suatu Pengantar Praktik. Bandung: Alfabeta.

Imron, A. 2012. Kebijaksanaan Pendidikan di Indonesia (Proses, Produk, \& Masa Depannya). Jakarta: Bumi Aksara.

Komariah, A. \& Triatna, C. 2010. Visionary Leadership (Menuju Sekolah Efektif). Jakarta: Bumi Aksara.

Mulyasa, H. E. 2012. Manajemen Pendidikan Karakter. Jakarta: Bumi Aksara.

Susanto, A. T. \& Muhyadi. 2016. Peran Kepala Sekolah dalam Pengembangan Kompetensi Guru di Sekolah Menengah Pertama Negeri. Jurnal Akuntabilitas Manajemen Pendidikan, (Online), 2 (2): 150-163, (http:// journal.uny.ac.id/index.php/jamp), diakses 2 Februari 2018. 